\title{
The Effect Of 7E Learning Cycle Model toward Student's Learning Outcomes of Basic Science Concept
}

\author{
Riri Marfilinda ${ }^{1}$,Rona Rossa ${ }^{1}$,Jendriadi ${ }^{1}$,Sry Apfani ${ }^{1}$ \\ 1 Prodi PGSD STKIP Adzkia, Padang, Indonesia \\ *ririmarfilinda@gmail.com
}

\begin{abstract}
This study aims to investigate the effect of the application of the 7E (Elicit, Engange ,Explore, Explain, Elaborate, Evaluation and Extend) Learning Cycle Model to the learning outcomes of the Basic Science Concepts of second grade student of Elementary School. This research is a quasi-experimental study with a randomized pretest-posttest control group design. The population of this study was all students of Primary Teacher Education in higher educational private university college in Padang in the 2018/2019 school year. The sample consisted of 24 control class students and 28 experimental class students. The experimental class uses the 7E Learning Cycle model while the control class uses the conventional model. The data collection technique is in the form of a learning outcome test (cognitive). From this study, there were differences in student learning outcomes using learning with the learning model Cycle 7E with conventional learning. Learning with 7E Learning Cycle model gives an effect of $72 \%$ (moderate) to the improvement of student learning outcomes in the Basic Science Concept Course.
\end{abstract}

Keywords: TE learning cycle model; learning outcomes; teaching basic science concept.

\section{INTRODUCTION}

This Learning in higher education is not much different from learning at other educational levels which is basically how to direct students to achieve the expected learning goals. This learning should pay attention to how the condition of individual students, what material will be learned, how the material is taught, what are the sources and tools used and all of this requires a teaching staff able to manage this.
Talking about Learning in Elementary School, we cannot be separated from all fields of science taught at these elementary schools and one of them is Natural Sciences (IPA). Science is part of the field of science that must be mastered by prospective elementary school teachers. Science is a systematic collection of theories, its application is generally limited to natural phenomena, born, and develop through scientific methods such as observation and 
experimentation and demands scientific attitude (Trianto, 2010)(Trianto, 2010). In accordance with the times, science has become a very influential and indispensable science in life.

Basic Science Concept Subjects require students with a variety of activities that make them interact with the environment, real objects, and other concrete matters related to science learning materials, so that later on through the experience gained they will be easier to increase their curiosity, able to gather information as much as possible, combining information, finding patterns, and making generalizations based on their findings independently. Learning like this will make student learning more meaningful. As the focus of meaningful learning is in accordance with the view that learning is constructing knowledge, in which students try to understand their experiences (Anderson \& Krathwohl, 2010).

Based on the early reflections on the subject of Basic Science Concept some of the problems found in learning this subject have not been able to fully meet the science learning standards. Students who tend to understand the concept only from the lecturer's explanation without discovering it themselves and developing their prior knowledge. Students only memorize but cannot construct their own knowledge. In addition,they are lazy to do practical work so they are not challenged to study science. The concept of science that is learned on campus has not been widely used in solving problems in live (Rossa, 2017). Thus, learning methods and models are implemented on campus are more teacher center. This is what makes student learning outcomes become low and their thinking skills are not honed.

One way to achieve success in the learning process is to link old understanding with new understanding. This process is in accordance with the process of constructivism in which students build their own thinking based on their initial knowledge. The constructivist learning model stems from Piageat's theory of intellectual development in which learning as a process of self regulation is carried out by someone in overcoming cognitive conflict (Turgut, Colak, \& Salar, 2017). Cognitive conflict arises when there is an interaction between the initial knowledge that students have had with new phenomena. This process is not easily integrated but it is necessary to change or modify the cognitive structure towards balance (Widodo, Wuryastuti, \& Margaretha, 2007). Therefore, Basic Science Concept should emphasize learner-centered learning, resulting in meaningful learning and not just rote learning. For this reason, there is a need for renewal and improvement in the learning process that prioritizes the achievement of learning outcomes in the form of processes and products. One of the efforts is through the application of constructivist paradigm oriented models. 


\section{LITERATURE REVIEW}

Basicly every model of the teachings have any advantages according the situation with the teacher used (Rahmatika, Maielfi, \& Jendriadi, 2019). One learning model that applies constructivism is the learning cycle. Learning Cycle is a student centered model. Learning This cycle provides opportunities for students to develop self-confidence through the active involvement of students during the learning process (Polyiem, Nuangchalerm, \& Wongchantra, 2011)

In 1970 based on the theory of cognitive development Jean Piaget, director of the Science Curiculum Improvement Studies, Robert Karplus, proposed a learning strategy in the form of a learning cycle. Learning cycle is a teaching strategy that is formally used in elementary school science programs, namely the Science Curriculum Improvement Study (SCIS). Although this strategy was first implemented in elementary schools, several studies have shown that the application of this teaching technique has been widespread at various grade levels, including the University (Marfilinda, Zaturrahmi, \& Suma Indrawati, 2019). Learning Cycle is a series of stages of activities (phases) organized in such a way that learners can master the competencies that must be achieved in learning by playing an active role (Ngalimun, 2014). Learning Cycle Model is also a case of the process of knowledge construction well, students will be able to increase their understanding of the material being studied so that meaningful learning is achieved.

Based on the development of Einsenkraft (Eisenkraft, 2003), 7E Learning Cycle model was born as a development of $5 \mathrm{E}$ which is included in the learning cycle model. The development of the $5 \mathrm{E}$ learning cycle into the 7E learning cycle occurs at certain stages, namely the Engage to Elicit and Engage stages while the Elaborate and Evaluate stages become three stages, namely Elaborate, Evaluate, and Extend. Based on the explanation of Einsenkraft (2003: 56), the seven stages of the 7E learning cycle are: a) Elicit (eliciting students' initial understanding) The teacher tries to raise or bring in student's initial knowledge by giving fundamental questions relating to the material to be studied. 7E Learning Cycle, which is part of constructivist learning, prioritizes prior knowledge or understanding which will later become the foundation for new knowledge. "The primary aim of the 7E Learning Cycle is to highlight the increasing importance of provoking previous understanding of transferring the concept to new contexts" (Balta \& Sarac, 2016). b) Management (involving): This activity aims to get students' attention, encourage their thinking skills, and help them access the initial knowledge they already have. c) Exploration (investigating). Students are given the opportunity to work both independently and in groups without direct instruction or direction from the teacher. Students manipulate an object, conduct experiments, investigate, 
observe, collect data, to make preliminary conclusions from experiments conducted. d) Explanation (explaining). Teachers encourage students to explain the concepts and definitions they understand in their own words and show examples related to the concept to complete the explanation. e) Elaboration (outlining) where students apply symbols, definitions, concepts, and skills to problems related to the examples of lessons learned. f) Evaluation (assessing) where the teacher evaluates the learning outcomes which has been done. At this stage a variety of assessment strategies can be used both formally and informally. G) Extends (extending) where students are required to think, search, discover, and explain examples of the application of new concepts and skills that have been learned.

The seven stages above are the steps taken by lecturers and students in applying this learning model in the class. Students and lecturers have their respective roles in each learning activity undertaken. This is so the advantages and benefits of this model can be felt. Some of the advantages of this cycle learning model are (Duran, Duran, Haney, \& Scheuermann, 2011), (Candra \& Achmadi, 2017),(Marfilinda, 2019), namely: (1) Can stimulate students to recall previous material, (2) can improve student learning towards better because this model prioritizes student experience but it also can form active, critical and creative students. (3) motivate students to be more active and increase curiosity,
(4) train students to learn concepts through experimental activities, etc.

Based on the existing problems and considering the advantages of the Learning Cycle model, the authors are interested in conducting research by applying this 7E Learning cycle model .

\section{METHODS}

This research is an experimental research. The population of this study were all first year students of 2018/2019. The Sample of this study were 2 classes selected randomly. The experimental class were 28 student and the control class were 24 student. The design in this study is classified as Randomized pretestposttest Control Group Design. Data collection tecniques using test techniques consisting of 30 problems of multiple choice about "ecosystem and Environmental Balance'. Analysis of the data by giving a pretest and posttest then the data obtained was then analyzed to obtain the results of the study .

\section{Research Stages}

To achieve the stated research objectives, systematic procedures need to be developed. In general, research procedures can be divided into three stages, namely the preparation, implementation and completion stages.

\section{a. Preparation phase}

At this stage the researcher did (1) set the research schedule, (2) prepare everything related to the learning tools starting from the syllabus, lesson plans, teaching materials in the form of 
compilation of materials obtained from several sources based on the 7E Learning Cycle model, (3) prepare final test questions about Ecosystem material, (4) validate by research expertise (5) test questions in class II $B$ that are not sample classes, (6) determine the sample population ie 4 population classes (7), specify the experiment class and control class.

\section{b. Implementation phase.}

At the implementation stage in accordance with the Flow diagram in the following figure:

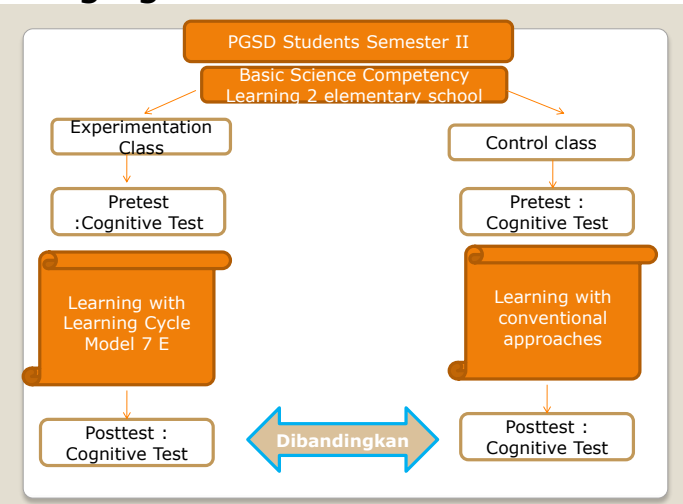

Figure 1. Research flow chart

In this study different treatments were given to the two sample classes. the implementation of learning is done from 2 classes chosen randomly, namely students in semester II D become experimental class and semester II A become Control class. The first class used 7E Learning Cycle model called the experimental class while the second class is the control used conventional learning. At the beginning of learning both classes were given a pretest in the form of a cognitive test and at the end of the learning both classes were given post test.

\section{c. Settlement Stage}

At this stage of completion, the final test will be carried out to obtain data, process data, and draw conclusions from the results obtained. Analysis of the results of research in the form of quantitative data that is the results of cognitive tests conducted using t-tests that were previously conducted normality tests and homogeneous tests first.

\section{RESULTS}

Our purpose in this work is to evaluate the impact of teaching Basic Science Concept throught 7E Learning Cycle Model to Learning Outcome of Primary Teacher Education's student. Therefore, we tried to make certain wether there was a meaningful difference between Learning outcome of Experiment's class and control's class.

According to stage of 7E learning Cycle Model, student in experiment class be must follow all activity in the class. Based on the first step taken, Elicit, students were asked to pay attention to the slide show in front of the class about ecosystems, lecturers trying to open up their old knowledge and connect with new knowledge. In the second step, Engagement, students are asked to do a simple experiment in front of the class, this is useful to arouse their interest in learning. With a demonstration in front of the class, students become more interested in learning and ask lots of questions and discussions. In the third 
step, exploration, students were divided into groups, then given a group activity sheet and each group worked on group work instructions. In this activity, it is very important for each student's thinking power to work and study because they are faced with various problems and how to overcome them so that they are critical in acting. Likewise with the next stage of explaining, students are invited to convey verbally what they have captured from the group work. between one student and another student there is mutual discussion and exchange of opinions and thoughts. Here the lecturer only acts as a facilitator. And in the next stage, elaborate, students are again invited to overcome various problems related to ecosystems and environmental balance so that they are able to apply existing concepts to everyday problems. And the final step is Evaluate and Extend, students are invited to evaluate what they have gotten and after that develop existing concepts to be applied to the surrounding activities.

And the finish data is in the form of student learning outcomes in Basic Science Concept Subject about Ecosystems and Environmental Balance. Student learning outcomes include pretest and posttest learning outcomes. This can be seen in table 1 below:

Table 1. Student Learning Outcomes by treatment class

\begin{tabular}{lllrrl}
\hline Class & Result & N & Min & Max & $\dot{X}$ \\
\hline Control class & Pretest & 24 & 10 & 70 & 42,08 \\
& Postest & 24 & 37 & 87 & 56,39 \\
Experiment class & Pretest & 28 & 43 & 86 & 54,07 \\
& Postest & 28 & 40 & 97 & 76,00 \\
\hline
\end{tabular}

From the research data above, the prerequisite test analysis is carried out, namely the normality test and below:

homogeneity test using SPSS 21 and the results in Tables 2 and 3 are listed Table 2. Normality test

KOGNITIF Kolmogorov-Smirnov ${ }^{\mathrm{a}} \quad$ Shapiro-Wilk

\begin{tabular}{lccccrcc} 
& & Statistic & $\mathrm{df}$ & Sig. & Statistic & df & Sig. \\
\hline \multirow{2}{*}{ MODEL } & 1 & .139 & 24 & $.200^{*}$ & .943 & 24 & .193 \\
& 2 & .143 & 28 & .150 & .951 & 28 & .204 \\
\hline
\end{tabular}

$*$. This is a lower bound of the true significance.

a. Lilliefors Significance Correction

Tabel 3.Test of Homogeneity of Variances

\begin{tabular}{clll}
\hline Levene Statistic & df1 & df2 & Sig. \\
\hline .773 & 1 & 50 & .383 \\
\hline
\end{tabular}


In the analysis prerequisite test consists of a normality test of all values and specifically the postest value shows that the data are normally distributed, that is in the Shapiro Wilk column showing a sign value $>0.05$, then the data is normally distributed. Likewise with the Homogeneous test in table 3 shows the Sign value in the form of
0.383> 0.05 then the homogeneous data.

After the prerequisite tests are carried out and the results are obtained that the data are normality and homogeneous, then it is continued with the hypothesis test using $\mathrm{t}$ test. This test was also carried out using SPSS 21 and the results obtained in table 4 below :

Table 4. Test t Results

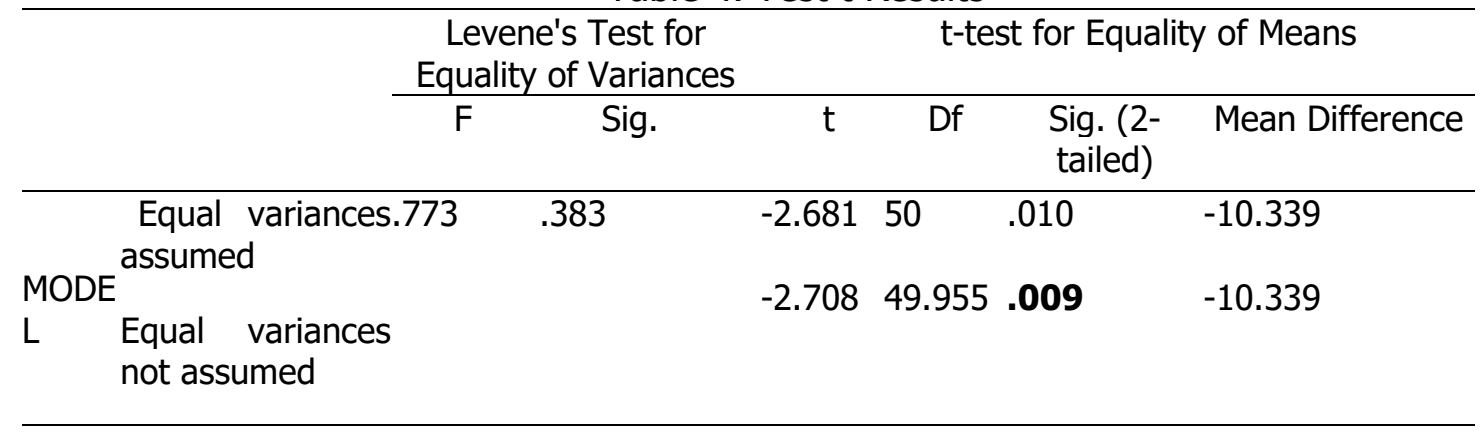

From the table 4, results of the $t$ test on the posttest value showed that the Sig (2-tailed) value in both columns was $<0.05$. Because our data is homogeneous, the line read is on the Equal Variances not assumed line which shows the number 0.009 , which means $<0.05$ with the conclusion that there is a difference between the learning outcomes of the posttest students who learn using the Learning Cycle $7 \mathrm{E}$ model and students who learn using conventional models. This means that there is an influence of the use of this model on learning.

This is also evidenced by the size of the effect size obtained by using the Cohen's $d$ formula which shows the value of influence of 0,72 or $72 \%$ which is in the medium criteria, meaning that the effect of using this model affects learning outcomes at a moderate level.

\section{DISCUSSION AND CONCLUSION}

The 7E Learning Cycle model has a great influence on learning outcomes. This is due to the many advantages and added values of this model through the steps that require students to be active in building their knowledge and understanding of learning material. Students are not only asked to memorize the material taught but also how they understand what has been taught and apply the concept in their lives.

The application of the 7E Cycle learning model has a positive impact on student learning outcomes and critical thinking skills. The combination of these models has a positive impact on lecturers 
because it helps lecturers revive a pleasant and not boring learning atmosphere. The positive impact for students is to reopen their minds to be able to think deeply.

In some of the literature, it can be concluded that Learning Cycle has a long history in science education. Although, there are various versions of the approach, all starting with an explicit stage to take students' attention and connect their prior knowledge. In addition, all inquiry models, the role of the teacher facilitator and become to apply the knowledge learned to the new situation. There are studies that support the effectiveness of approaches to obtain scientific concepts and skills. It was found that learning cycles lead to better acquisition of scientific conceptions than traditional methods. Furthermore, Gok (Gok, 2014) states that "The cycle phase provides an opportunity for students to focus on and become interested in the lesson, actively engage in the process, use their prior knowledge and build new knowledge with the help of previous experiences, develop inquiry skills and self evaluation".

In the same way, studies show that the learning cycle is an effective method to clarify students' thought processes and to correct their misconceptions (Shaheen \& Kayani, 2015). According to Odom and Kelly (Odom \& Kelly, 2001), the Learning Cycle phase helps students to explore their belief systems and provides knowledge construction and selfregulation skills by developing inquiry skills such as argumentation, prediction and hypothesis testing. Likewise, Marfilinda (Marfilinda, Rossa, \& Apfani, 2019) reports that the learning cycle fosters inquiry and gives students a situation in which students are able to work together, explore, ask questions and look for scientific explanations and answers. In addition, researchers add that students gain valuable skills that they also need in their future lives in the Learning Cycle.

The results of hypothesis testing revealed that the overall learning outcomes of the experimental class students applying the 7E Cycle learning model were significantly higher than those of the control class. This can be seen from the posttest mean score of the experimental class 76.10 and the control class below that is 56.39. The high acquisition of the average value of this experimental class compared to the control class is caused by the effect of the treatment given to the experimental class, namely the 7E Learning Cycle model. This is also supported by the results of Ozlem Mecit's research (Mecit, 2006) which revealed that the 7E Learning Cycle Model causes better improvements in critical thinking skills than conventional methods ".

The 7E Cycle learning model in the experimental class can improve students' learning towards better and their critical thinking skills improve better because this model is student-centered, helps students learn to find themselves, explore their own thoughts, students can learn how to think better, and critically. This is also consistent with Ni Meldania's 
research (Meldania, 2013) which states that learning using the 7E Learning Cycle model enhances student learning activities and outcomes because this model prioritizes student experiences and can also form active, critical and creative students.

And finally, learning with the learning model Cycle 7 can improve student learning outcomes because students are required to actively learn where students discover various concepts of learning from direct experience. This makes it easier for their brains to easily record and understand learning so that it impacts on improving their learning outcomes.(Sole \& Wilujeng, 2013)

Based on the analysis of research data and the discussion that has been described, the conclusion that can be obtained is the Learning Cycle 7E learning model significantly influences the learning outcomes of KD Science Natural 2, where the average posttest learning outcomes of experimental class students are significantly more significant compared to student grades in the classroom control. This is also strengthened by the magnitude of the influence of this model by $72 \%$ with the Cohen's formula.(Gayatri, Bahar, \& Handayani, 2017)

This proves that the Learning Cycle Model can influence learning outcomes because of the several steps this model is able to invite students to develop their thinking power so that learning becomes meaningful and how students learn to construct their own understanding through the steps passed in learning. It is expected that in the future this learning cycle Learning model can be adapted in science learning and is able to provide changes not only to the science learning outcomes but also to other aspects of science.

\section{ACKNOWLEDGMENT}

The authors thank the Ministry of Research, Technology and Higher Education on the Republic of Indonesiafor funding this project. The preliminary of this article has been presented in the International Conference on Islamic Education (ICIE), UIN Imam Bonjol Padang, Nov 28-29, 2019.

\section{REFERENCES}

Anderson, L. W., \& Krathwohl, D. R. (2010). Kerangka Landasan untuk Pembelajaran, Pengajaran dan Asesmen. Yogyakarta: Pustaka Belajar.

Balta, N., \& Sarac, H. (2016). The Effect of 7E Learning Cycle on Learning in Science Teaching: A meta-Analysis Study. European Journal of Educational Research, 5(2), 61-72. https://doi.org/10.12973/eujer.5.2.61

Candra, I. A., \& Achmadi, H. R. (2017). Model Pembelajaran Learning Cycle 7E untuk Meningkatkan Motivasi dan Hasil Belajar Siswa pada Materi Gerak Harmonik Kelas X di SMAN 1. Jurnal Inovasi Pendidikan Fisika (JIPF), 06(03), 83-90.

Duran, E., Duran, L., Haney, J., \& Scheuermann, A. (2011). A Learning 
Cycle for All Students (Vol. 78, pp. 56-60). Retrieved from http://search.ebscohost.com/login.as px?direct $=$ true $\& \mathrm{db}=$ eric $\& A N=E J 921$ 653\&site=ehostlive\%5Cnhttp://www.nsta.org/public ations/browse_journals.aspx?action =issue\&id=10.2505/3/tst11_078_03

Eisenkraft, A. (2003). Expanding the 5E model. The Science Teacher, 70(6), 56-59.

Gayatri, E. R. P., Bahar, A., \& Handayani, D. (2017). Perbandingan penerapan model pembelajaran learning cycle ( 5e ) dan two stay two stray. Jurnal Pendidikan Dan IImu Kimia, 1(1), 71-74.

Gok, G. (2014). The Effect of 7e learning cycle instruction on 6th grade Student's Conceptual Understanding of Human Bod System, Self Regulation, Scientific Epistemilogical Beliefs and Science Process Skills. Middle East Technical University.

Marfilinda, R. (2019). Pengaruh Model Learning Cycle 7 e dan pengetahuan awal terhadap keterampilan berpikir kritis siswa pada pembelajaran ipa di kelas v sd, VI(02), 84-97.

Marfilinda, R., Rossa, R., \& Apfani, S. (2019). Pengaruh model learning cycle 7e terhadap hasil belajar dan keterampilan berpikir kritis, 01(02), 79-92.

Marfilinda, R., Zaturrahmi, \& Suma Indrawati, E. (2019). Development and application of learning cycle model on science teaching and learning: a literature review. Journal of Physics: Conference Series,
13171).

https://doi.org/10.1088/1742-

$6596 / 1317 / 1 / 012207$

Mecit, O. (2006). Tesis The Effect of 7E Learning Cycle Model On the Improvement of Fifth Grade Student's Critical Thinking, (September).

Meldania, N. P. (2013). Pengaruh Model Pembelajaran Learning Cycle 7E Bermuatan Tri Hita Karana Terhadap Hasil Belajar Ipa Siswa Kelas V, 2(2), 12.

Ngalimun. (2014). Strategi dan Model Pembelajaran. Yogyakarta: Aswaja Pressindo.

Odom, A. L., \& Kelly, P. V. (2001). Integrating concept mapping and the learning cycle to teach diffusion and osmosis to high school biology students. Science Education, 85.

Polyiem, T., Nuangchalerm, P., \& Wongchantra, P. (2011). Learning Achievement, Science Process Skills , and Moral Reasoning of Ninth Grade Students Learned by $7 e$ Learning Cycle and Socioscientific Issue-based Learning. Australian Journal of Basic and Applied Science, 5(10), 257-263.

Rahmatika, N., Maielfi, D., \& Jendriadi. (2019). Proceeding ASEAN Youth Conference Website: http://jurnal.aycppim.id/index.php/a $\mathrm{yc} /$ The effects of treffinger learning model towards science learning outcomes in class $v$ SDN 43 Sungai Sapih Padang, (October), 12-13. Retrieved from http://jurnal.aycppim.id/index.php/a 


\section{yc/}

Rossa, R. (2017). the effect of teaching critical thinking skill through problem solving technique toward students' writing skill in STKIP ADZKIA Padang. Handayani, $7(2), 25$.

Shaheen, M. N. U. K., \& Kayani, M. M. (2015). Improving Students' Achievement in Biology using 7E Instructional Model: An Experimental Study. Mediterranean Journal of Social Sciences, 6(4), 471-481. https://doi.org/10.5901/mjss.2015.v $6 \mathrm{n} 4 \mathrm{~s} 3 \mathrm{p} 471$

Sole, F. B., \& Wilujeng, I. (2013). Pengaruh Implementasi the 4-E Learning Cycle terhadap Pengetahuan, Keterampilan Proses Dasar, dan Sikap Ilmiah IPA Siswa
SDK Kererobbo. Jurnal Prima Edukasia, 1(1), 43-50.

Trianto. (2010). Model Pembelajaran Terpadu, Konsep, Strategi, dan Implikasi dalam Kurikulum Tingkat Satuan Pendidikan (KTSP). Jakarta: Bumi Aksara.

Turgut, U., Colak, A., \& Salar, R. (2017). How Is the Learning Environment in Physics Lesson With Using 7E Model Teaching Activities. European Journal of Education Studies, 3(6), 1-28. https://doi.org/10.5281/zenodo.571 250

Widodo, A., Wuryastuti, S., \& Margaretha. (2007). Pendidikan IPA di SD. Bandung: UPI Press. 